\title{
Bibliography
}

\author{
Primary sources
}

Archival collections

BBC Written Archives Centre, Peppard Road, Caversham Park, Reading.

Lothian Health Services Archive, University of Edinburgh Centre for Research Collections, Main Library, George Square, Edinburgh:

- Royal Edinburgh Hospital Archive

Modern Records Centre, University Library, University of Warwick, Coventry:

- Association of Psychiatric Social Work Archive

- Confederation of Health Service Employees Archive

- National Asylum Workers' Union / Mental Hospital and Institutional Workers' Union Archive

The National Archives, Kew, Richmond, Surrey:

- Ministry of Health Records

NHS Greater Glasgow and Clyde Archives, the Mitchell Library, Glasgow:

- Gartnavel Royal Hospital Archives

Wellcome Library, London:

- Mental After Care Association Archives

- Robina Addis Archive

- William Sargant Collection

\section{Published sources}

Allen, H., 'A narrative of God's gracious dealings with that choice Christian Mrs. Hannah Allen' (1683), in A. Ingram (ed.) Voices of Madness: Four Pamphlets, 16831796 (Stroud, 1997), pp. 1-22.

Altschul, A., 'The role of the psychiatric nurse in the community', in Association of Psychiatric Social Workers, New Developments in Psychiatry and the Implications for the Social Worker (London, 1969), pp.37-9.

Anonymous, 'They said I was mad', Forum and Century, 100 (1938), 231-7.

Anonymous, The Autobiography of David, edited by Ernest Raymond (London, 1946).

Barnes, M. and Berke, J., Two Accounts of a Journey through Madness (London, 1971).

Beers, C., A Mind that Found Itself: An Autobiography (London, 1908).

Belcher, W., 'Address to humanity: containing, a letter to Dr. Monro; a receipt to make a lunatic, and seize his estate; and a sketch of a true smiling hyena' (1796), in A. Ingram (ed.) Voices of Madness: Four Pamphlets, 1683-1796 (Stroud, 1997), pp. 127-36. 
Brown, G. W., Bone, M., Dalison, B. and Wing, J. K., Schizophrenia and Social Care: A Comparative Follow-Up Study of 339 Schizophrenic Patients (London, 1966).

Bruckshaw, S., 'One more proof of the iniquitous abuse of private madhouses' (1774), in A. Ingram (ed.) Voices of Madness: Four Pamphlets, 1683-1796 (Stroud, 1997), pp. $75-126$.

Clarke, D. H., The Story of a Mental Hospital: Fulbourn 1858-1983 (London, 1996).

Clouston, T., The Hygiene of the Mind (London, 1906).

Crichton-Browne, J., Burns, From a New Point of View (London, 1926).

Crichton-Browne, J., The Doctor's Second Thoughts (London, 1931).

Crichton-Browne, J., The Doctor Remembers (1932; London, 1938).

Crichton-Browne, J., From the Doctor's Notebook (London, 1937).

Crichton-Browne, J., Stray Leaves from a Physician's Portfolio (London, 1938).

Cruden, A., 'The London-citizen exceedingly injured' (1739), in A. Ingram (ed.) Voices of Madness: Four Pamphlets, 1683-1796 (Stroud, 1997), pp. 23-74.

Gibson, G., edited by W. Gibson, Reminiscences (Eastbourne, 2004).

Grant-Smith, R., The Experiences of an Asylum Patient with an Introduction and Notes by Montagu Lomax M.R.C.S. (London, 1922).

Hamilcar, M., Legally Dead: Experiences during Seventeen Weeks' Detention in a Private Asylum with an Introduction by Dr. Forbes Winslow (London, 1910).

Irwin, E., Mitchell, L., Durkin, L. and Douieb, B., 'The need for a mental patients' union' (1972). Reproduced on the webpage: http://studymore.org.uk/mpu. htm\#FishPamphlet.

Laing, R. D., The Divided Self: An Existential Study in Sanity and Madness (1959; Harmondsworth, 1965).

Laing, R. D., Wisdom, Madness and Folly: The Making of a Psychiatrist 1927-1957 (1985; London, 1986).

Laurie, K., Employable or Unemployable? Report on Pioneer Experimental Work Covering the Period February 61939 - August 11940 (London, 1941).

Lomax, M., The Experiences of an Asylum Doctor with Suggestions for Asylum and Lunacy Law Reform (London, 1921).

Martin, D. V., Adventure in Psychiatry: Social Change in a Mental Hospital (Oxford, 1962).

Maudsley, H., The Physiology and Pathology of the Mind (London, 1867).

Mayhew, C., Time to Explain: An Autobiography (London, 1987).

McDougall, K. F., 'Chairman's introduction', in E. M. Goldberg, E. E. Irvine, A. B. Lloyd Davies and K. F. McDougall (eds), The Boundaries of Casework: A Report on a Residential Refresher Course Held by the Association of Psychiatric Social Work (London, 1959), p. 8.

Medico-Psychological Association, Handbook for Attendants on the Insane (London, 1908).

Ministry of Health, Report of the Committee on Administration of Public Mental Hospitals, Cmd. 1730 (London, 1922).

Ministry of Health, Report of the Departmental Committee on Sterilisation, Cmnd. 4485 (London, 1934). 
Ministry of Health, Report of the Working Party on Social Workers in Local Authority Health and Welfare Services (London, 1959).

Osbaldeston, M., 'Nobody wants to know', in B. Robb, Sans Everything: A Case to Answer (London, 1967), pp. 13-18.

Report of the Committee on Medical Auxiliaries, Cmd. 8188 (London, 1951).

Report of the Interdepartmental Committee on Mental Deficiency, 1925-1929 (London, 1929).

Report of the Royal Commission on the Law Relating to Mental Illness and Mental Deficiency, Cmnd. 169 (London, 1957).

Report of the Tribunal Appointed to Inquire into Allegations Reflecting on the Official Conduct of Ministers of the Crown and Other Public Servants, Cmd. 7617 (1949).

Robb, B., Sans Everything: A Case to Answer (London, 1967).

Robinson, P. (director), Asylum (film, 1971).

Rolph, C. H., 'Cruelty in the old people's ward', in B. Robb, Sans Everything: A Case to Answer (London, 1967), pp. 3-7.

Sargant, W., The Unquiet Mind: The Autobiography of a Physician in Psychological Medicine (London, 1967).

Sargant, W. and Slater, E., An Introduction to Physical Methods of Treatment in Psychiatry (Edinburgh, 1948).

Second Report from the Social Services Committee Session 1984-85: Community Care with Special Reference to Adult Mentally Ill and Mentally Handicapped People (London, 1985).

Smith, T., 'The role of the psychiatric nurse in the community', in Association of Psychiatric Social Workers, New Developments in Psychiatry and the Implications for the Social Worker (London, 1969), pp. 40-6.

Stafford-Clarke, D., Psychiatry To-day (1952; London, 1963).

Timms, N., Psychiatric Social Work in Britain, 1939-1962 (London, 1964).

Vincent, J., Inside the Asylum (London, 1948).

Wing, J. K., 'Trends in the care of the chronically mentally disabled', in J. Wing and R. Olsen (eds), Community Care for the Mentally Disabled (Oxford, 1979), pp. 1-13.

Wing, J. K., Bennett, D. H. and Denham, J., The Industrial Rehabilitation of Long-Stay Schizophrenic Patients: A Study of 45 Patients at an Industrial Rehabilitation Unit: MRC Memorandum No. 42 (London, 1964).

Wing, J. K. and Brown, G. W., Institutionalism and Schizophrenia: A Comparative Study of Three Mental Hospitals 1960-1968 (Cambridge, 1970).

Wootton, B., Social Science and Social Pathology (1959; London, 1963).

Yellowlees, H., To Define True Madness: Commensense Psychiatry for Lay People (1953; Harmondsworth, 1955).

\section{Newspapers and periodicals}

British Journal of Psychiatric Social Work

British Medical Journal

Daily Record 
Daily Telegraph and Morning Post

Health Services Journal

Journal of Applied Behavior Analysis

Journal of Mental Science

Lancet

Mental Hospital and Institutional Workers' Union Journal

National Asylum Workers' Union Magazine

Pall Mall Gazette

The Times

Truth

\section{Secondary sources}

Printed sources

Anderson, J., War, Disability and Rehabilitation in Britain: 'Soul of a Nation' (Manchester, 2011).

Andrews, J., 'R. D. Laing in Scotland: facts and fictions of the "rumpus room" and interpersonal psychiatry', in M. Gijswijt-Hofstra and R. Porter (eds), Cultures of Psychiatry and Mental Health Care in Postwar Britain and the Netherlands (Amsterdam, 1998), pp. 121-40.

Andrews, J. and Digby, A., 'Introduction', in J. Andrews and A. Digby (eds), Sex and Seclusion, Class and Custody: Perspectives on Gender and Class in the History of British and Irish Psychiatry (Amsterdam and New York, 2004), pp.7-44.

Andrews, J. and Scull, A., Customers and Patrons of the Mad-Trade: The Management of Lunacy in Eighteenth-Century London with the Complete Text of John Monro's 1766 Case Book (London, 2003).

Appignanesi, L., Mad, Bad and Sad: A History of Women and the Mind Doctors since 1800 (London, 2008).

Barfoot, M. and Beveridge, A., 'Madness at the crossroads: John Home's letters from the Royal Edinburgh Asylum, 1886-87', Psychological Medicine, 20 (1990), 263-84.

Barham, P., Closing the Asylum: The Mental Patient in Modern Society (Harmondsworth, 1997).

Barham, P., Forgotten Lunatics of the Great War (London, 2004).

Barham, P. and Hayward, R., Relocating Madness: From the Mental Patient to the Person (London, 1995).

Bartlett, P., 'The asylum and the Poor Law: the productive alliance', in J. Melling and B. Forsythe (eds), Insanity, Institutions and Society, 1800-1914: A Social History of Madness in Comparative Perspective (London, 1999), pp.48-64.

Bartlett, P. and Wright, D. (eds), Outside the Walls of the Asylum: The History of Care in the Community 1750-2000 (London and New Brunswick, 1999).

Berridge, V., 'Medicine and the public: the 1962 Report of the Royal College of Physicians and the new public health', Bulletin of the History of Medicine, 81 (2007), 286-311. 
Berridge, V., 'Medicine, public health and the media in Britain from the nineteen-fifties to the nineteen-seventies', Historical Research, 82 (2009), 360-73.

Beveridge, A., 'Voices of the mad: patients' letters from the Royal Edinburgh Asylum, 1873-1908', Psychological Medicine, 27 (1997), 899-908.

Beveridge, A., 'Life in the asylum: patients' letters from Morningside, 1873-1908', History of Psychiatry, 9 (1998), 431-69.

Beveridge, A., Portrait of the Psychiatrist as a Young Man: The Early Writing and Work of R. D. Laing, 1927-1960 (Oxford, 2011).

Boston, S., Women Workers and the Trade Unions (London, 1980).

Bourdieu, P., Distinction: A Social Critique of the Judgement of Taste (1979; translation by Richard Nice 1984: Abingdon, 2005).

Bourdieu, P., On Television and Journalism (London, 1998).

Braybon, G., Women Workers in the First World War (London and New York, 1981).

Burleigh, M., Death and Deliverance: 'Euthanasia' in Germany 1900-1945 (Cambridge, 1994).

Bury, M., 'Illness narratives: fact or fiction?', Sociology of Health and Illness, 23 (2001), 263-85.

Busfield, J., 'The female malady? Men, women and madness in nineteenth century Britain', Sociology, 28 (1994), 259-77.

Busfield, J., Men, Women and Madness: Understanding Gender and Mental Disorder (Houndmills, 1996).

Busfield, J., 'Restructuring mental health services in twentieth-century Britain', in M. Gijswijt-Hofstra and R. Porter (eds), Cultures of Psychiatry and Mental Health Care in Postwar Britain and the Netherlands (Amsterdam, 1998), pp.9-28.

Butler, T., Changing Mental Health Services: The Politics and Policy (London, 1993).

Cantor, D., 'Representing "the public": medicine, charity and emotion in twentiethcentury Britain', in S. Sturdy (ed.), Medicine, Health and the Public Sphere in Britain, 1600-2000 (London, 2002), pp. 145-68.

Carpenter, M., 'Asylum nursing before 1914: a chapter in the history of labour', in C. Davies (ed.), Rewriting Nursing History (London, 1980), pp. 123-46.

Carpenter, M., Working for Health: The History of the Confederation of Health Service Employees (London, 1988).

Carpenter, M., Normality Is Hard Work: Trade Unions and the Politics of Community Care (London, 1994).

Carr, E. H., What Is History? (1961; Harmondsworth, 1990).

Cherry, S., Mental Health Care in Modern England: The Norfolk Lunatic Asylum / St Andrew's Hospital c.1810-1998 (Woodbridge, 2003).

Chesler, P., Women and Madness (1972: New York, 1973).

Clark, M. J., 'Law, liberty and psychiatry in Victorian Britain: an historical survey and commentary, c. 1840-1890', in L. de Goei and J. Vijselaar (eds), Proceedings of the First European Congress on the History of Psychiatry and Mental Health Care (Amsterdam, 1993), pp. 187-93.

Clarke, L., 'Joshua Bierer: striving for power', History of Psychiatry, 8 (1997), 319-32. 
Corrigan, P. W. (ed.), On the Stigma of Mental Illness: Practical Strategies for Research and Social Change (Washington, DC, 2005).

Cross, S., 'Visualizing madness: mental illness and public representation', Television \& New Media, 5 (2004), 197-216.

Cross, S., Mediating Madness: Mental Distress and Cultural Representation (Houndmills, 2010).

Crossley, N., 'R. D. Laing and the British anti-psychiatry movement: a socio-historical analysis', Social Science and Medicine, 47 (1998), 877-89.

Crossley, N., 'Transforming the mental health field: the early history of the National Association of Mental Health', Sociology of Health and Illness, 20 (1998), 458-88.

Crossley, N., Contesting Psychiatry: Social Movements in Mental Health (Abingdon, 2006).

Curran, J. and Seaton, J., Power Without Responsibility: The Press and Broadcasting in Britain (London, 1997).

Delap, L., Knowing Their Place: Domestic Service in Twentieth-Century Britain (Oxford, 2011).

Dingwall, R., Rafferty, M. and Webster, C., An Introduction to the Social History of Nursing (London, 1988).

Eghigian, G., 'Deinstitutionalizing the history of contemporary psychiatry', History of Psychiatry, 22 (2011), 201-14.

Fennell, P., Treatment without Consent: Law, Psychiatry and the Treatment of Mentally Disordered People since 1845 (London, 1996).

Finlayson, G., 'A moving frontier: voluntarism and the State in British social welfare 1911-1949', Twentieth Century British History, 1 (1990), 183-206.

Finlayson, G., Citizen, State, and Social Welfare in Britain, 1830-1990 (Oxford, 1994).

Foucault, M., Madness and Civilization: A History of Insanity in the Age of Reason (London, 1967).

Fraser, N., 'Rethinking the public sphere: a contribution to the critique of actually existing democracy', in C. Calhoun (ed.), Habermas and the Public Sphere (1992; Cambridge, Mass., 1999), pp. 109-42.

Freeman, H., 'Psychiatry and the state in Britain', in M. Gijswijt-Hofstra, H. Oosterhuis, J. Vijselaar and H. Freeman (eds), Psychiatric Cultures Compared: Psychiatry and Mental Health Care in the Twentieth Century (Amsterdam, 2005), pp. 116-40.

Future Vision Coalition, A Future Vision for Mental Health (n.p., 2009).

Gilman, S. L., The Face of Madness: Hugh W. Diamond and the Origin of Psychiatric Photography (New York, 1977).

Gilman, S. L., Disease and Representation: Images of Illness from Madness to AIDS (Ithaca and London, 1988).

Gittins, D., Madness in Its Place: Narratives of Severalls Hospital, 1913-1997 (London, 1998).

Goffman, E., Stigma: Notes on the Management of a Spoiled Identity (1963; Harmondsworth, 1968).

Griffiths, R., 'The bigger picture', Mental Health Today (January/February, 2012), 20. 
Habermas, J., The Structural Transformation of the Public Sphere, trans. T. Burger (1962; Cambridge, 1999).

Hacking, I., The Social Construction of What? (1999; Cambridge, Mass., 2000).

Hall, L. A., 'Essay review: does madness have a gender?', History of Psychiatry, 20 (2009), 497-501.

Hallam, J., Nursing the Image: Media, Culture and Professional Identity (London, 2000).

Harding, T. W., "'Not worth powder and shot": a reappraisal of Montagu Lomax's contribution to mental health reform', British Journal of Psychiatry, 156 (1990), 180-7.

Harris, B., The Origins of the Welfare State: Social Welfare in England and Wales, 18001945 (Basingstoke, 2004).

Harris, B., 'Voluntary action and the state in historical perspective', Voluntary Sector Review, 1 (2010), 25-40.

Henderson, L., 'Selling suffering: mental illness and media values', in G. Philo (ed.), Media and Mental Distress (Harlow, 1996), pp. 18-36.

Hess, V. and Majerus, B., 'Writing the history of psychiatry in the twentieth century', History of Psychiatry, 22 (2011), 139-45.

Hinshaw, S. P., The Mark of Shame: Stigma of Mental Illness and an Agenda for Change (Oxford, 2007).

Hornstein, G. A., Agnes's Jacket: A Psychologist's Search for the Meanings of Madness (2009; Ross-on-Wye, 2012).

Houston, R. A., "Not simple boarding”: care of the mentally incapacitated in Scotland during the long nineteenth century', in P. Bartlett and D. Wright (eds), Outside the Walls of the Asylum: The History of Care in the Community 1750-2000 (London, 1999), pp. 19-44.

Hughes, K., The Victorian Governess (London, 1993).

Ingram, A. (ed.), Voices of Madness: Four Pamphlets, 1683-1796 (Stroud, 1997).

Jackson, M., 'Images of deviance: visual representations of mental defectives in early twentieth-century medical texts', British Journal for the History of Science, 28 (1995), 319-37.

Jackson, M., The Borderland of Imbecility: Medicine, Society and the Fabrication of the Feeble Mind in Late Victorian and Edwardian England (Manchester, 2000).

Jenkins, K., Rethinking History (1991; Abingdon, 2009).

Joicey, N., 'A paperback guide to progress: Penguin books 1935 - c. 1951', Twentieth Century British History, 4 (1993), 25-56.

Jones, C., 'Raising the anti: Jan Foudraine, Ronald Laing and anti-psychiatry', in M. Gijswijt-Hofstra and R. Porter (eds), Cultures of Psychiatry and Mental Health Care in Postwar Britain and the Netherlands (Amsterdam, 1998), pp. 283-94.

Jones, K., Asylums and After. A Revised History of the Mental Health Services: From the Early 18th Century to the 1990s (London, 1993).

Karpf, A., Doctoring the Media: The Reporting of Health and Medicine (London, 1988).

Kitzinger, J., 'A sociology of media power: key issues in audience reception research', in G. Philo (ed.), Message Received: Glasgow Media Group Research 1993-1998 (Harlow, 1999), pp.3-20. 
Larkin, G., 'Health workers', in R. Cooter and J. Pickstone (eds), Companion to Medicine in the Twentieth Century (London, 2003), pp. 531-42.

Lewis, J., The Voluntary Sector, the State and Social Work in Britain: The Charity Organisation Society / Family Welfare Association Since 1869 (Aldershot, 1995).

Link, B. G. and Phelan, J. C., 'Conceptualizing stigma', Annual Review of Sociology, 27 (2001), 363-84.

Long, V., 'The Mental After Care Association: Public Representations of Mental Illness, 1879-1925’ (MA thesis, University of Warwick, 2000).

Long, V., 'Changing Public Representations of Mental Illness in Britain, 1870-1970' (PhD dissertation, University of Warwick, 2004).

Long, V., "'A satisfactory job is the best psychotherapist": employment and mental health, 1939-60', in P. Dale and J. Melling (eds), Mental Illness and Learning Disability since 1850: Finding a Place for Mental Disorder in the United Kingdom (Abingdon, 2006), pp. 179-99.

Long, V., The Rise and Fall of the Healthy Factory: The Politics of Industrial Health in Britain, 1914-60 (Basingstoke, 2011).

Long, V., "Often there is a good deal to be done, but socially rather than medically": the psychiatric social worker as social therapist, 1945-1970', Medical History, 55 (2011), 223-39.

Long, V., 'Rethinking post-war mental healthcare: industrial therapy and the chronic mental patient in Britain', Social History of Medicine, advance access, published online, 10 March 2013.

Long, V., "Surely a nice job for a girl?” Stories of nursing, gender, violence and mental illness in British asylums, 1914-1930', in P. Dale and A. Borsay (eds), Nursing the Mentally Disordered: Struggles that Shaped the Working Lives of Paid Carers in Institutional and Community Settings from 1800 to the 1980s (forthcoming).

Loughlin, K., "Your Life in Their Hands": the context of a medical-media controversy', Media History, 6 (2000), 177-88.

Lunbeck, E., The Psychiatric Persuasion: Knowledge, Gender and Power in Modern America (Princeton, 1994).

MacDonald, D. F., The State and the Trade Unions (London, 1976).

MacDonald, M., Mystical Bedlam: Madness, Anxiety, and Healing in Seventeenth-Century England (Cambridge, 1981).

Maw, J., 'Revealing the Mind Bender General', BBC documentary, broadcast on Radio 4 on 17 March 2009.

McCandless, P., "Build! build!" the controversy over the care of the chronically insane in England, 1855-1870', Bulletin for the History of Medicine, 53 (1979), 553-74.

McCandless, P., 'Liberty and lunacy: the Victorians and wrongful confinement', in A. Scull (ed.), Madhouses, Mad-Doctors and Madmen: The Social History of Psychiatry in the Victorian Era (Philadelphia, 1981), pp.339-61.

McCarthy, H. and Thane, P., 'The politics of association in industrial life', TwentiethCentury British History, 22 (2011), 217-29. 
McGann, S., Crowther, A. and Dougall, R., A History of the Royal College of Nursing 1916-90: A Voice for Nurses (Manchester, 2009).

Mehta, N., Kassam, A., Leese, M., Butler, G. and Thornicroft, G., 'Public attitudes towards people with mental illness in England and Scotland, 1994-2003', British Journal of Psychiatry, 194 (2009), 278-84.

Melling, J., 'Sex and sensibility in cultural history: the English governess and the lunatic asylum, 1845-1914', in J. Andrews and A. Digby (eds), Sex and Seclusion, Class and Custody: Perspectives on Gender and Class in the History of British and Irish Psychiatry (Amsterdam, 2004), pp. 177-219.

Melling, J., "Buried alive by her friends": asylum narratives and the English governess, 1845-1914', in J. Melling and P. Dale (eds), Mental Illness and Learning Disability since 1845: Finding a Place for Mental Disorder in the United Kingdom (Abingdon, 2006), pp.65-90.

Melling, J. and Forsythe, B., The Politics of Madness: The State, Insanity and Society in England, 1845-1914 (Abingdon, 2006).

Mitchell, D., 'Parallel stigma? Nurses and people with learning disabilities', British Journal of Learning Disabilities, 28 (2000), 78-81.

Muijen, M., 'Scare in the community: Britain in moral panic', in T. Heller, J. Reynolds, R. Gomm, R. Muston and S. Pattison (eds), Mental Health Matters: A Reader (Houndmills, 1996), pp. 143-55.

Neve, M. and Turner, T., 'What the doctor thought and did: Sir James CrichtonBrowne (1840-1938)', Medical History, 39 (1995), 399-432.

Nolan, P., A History of Mental Health Nursing (London, 1993).

Nolan, P., 'Annie Altschul's legacy to 20th century British mental health nursing', Journal of Psychiatric and Mental Health Nursing, 6 (1999), 267-72.

Nolan, P. and Hopper, B., 'Revisiting mental health nursing in the 1960s', Journal of Mental Health, 9 (2000), 563-73.

Norman, P., In the Way of Understanding - Part of a Life: Lantern Slides in a Rough Time Sequence (Godalming, 1982).

Nottingham, C., 'The rise of the insecure professionals', International Review of Social History, 52 (2007), 445-75.

Oakley, A., A Critical Woman: Barbara Wootton, Social Science and Public Policy in the Twentieth Century (London, 2011).

Parry-Jones, W., The Trade in Lunacy: A Study of Private Madhouses in England in the Eighteenth and Nineteenth Centuries (London, 1972)

Paterson, D., A Mad People's History of Madness (Pittsburgh, 1982).

Payne, S., 'Outside the walls of the asylum? Psychiatric treatment in the 1980s and 1990s', in P. Bartlett and D. Wright (eds), Outside the Walls of the Asylum: The History of Care in the Community 1750-2000 (London, 1999), pp. 244-65.

Philo, G., (ed.), Media and Mental Distress (Harlow, 1996).

Philo, G., 'The media and public belief', in G. Philo (ed.), Media and Mental Distress (Harlow, 1996), pp. 82-104. 
Philo, G., 'Users of services, carers and families', in G. Philo (ed.), Media and Mental Distress (Harlow, 1996), pp. 105-14.

Philo, G. (ed.), Message Received: Glasgow Media Group Research 1993-1998 (Harlow, 1999).

Philo, G., McLaughlin, G. and Henderson, L., 'Media content', in G. Philo (ed.), Media and Mental Distress (London, 1996), pp. 45-813.

Pickstone, J. V., 'Psychiatry in general hospitals: history, contingency and local innovation in the early years of the National Health Service', in J. V. Pickstone (ed.), Medical Innovations in Historical Perspective (Houndmills, 1992), pp. 185-99.

Plumb, A., '. . Distress or disability?' (1994), reproduced in J. Anderson, B. Sapey and H. Spandler (eds), Distress or Disability? Proceedings of a Symposium Held at Lancaster University, 15-16 November 2011 (Bowland North, 2012), pp. 4-12.

Pols, H., "Beyond the clinical frontiers": the American mental hygiene movement, 1910-1940', in V. Roelcke, P. Weindling and L. Westwood (eds), International Relations in Psychiatry: Britain, Germany and the United States to World War II (Rochester, 2010), pp. 111-33.

Porter, R., Mind-Forg'd Manacles: A History of Madness in England from the Restoration to Regency (Cambridge, Mass., 1987).

Porter, R. (ed.), The Faber Book of Madness (London, 1991).

Porter, R., 'Hearing the mad. Communication and excommunication', in L. de Goei and J. Vijselaar (eds), Proceedings of the First European Congress on the History of Psychiatry and Mental Health Care (Amsterdam, 1993), pp.338-52.

Porter, R., 'Psychiatry and its history: Hunter and Macalpine', in L. de Goei and J. Vijselaar (eds), Proceedings of the First European Congress on the History of Psychiatry and Mental Health Care (Amsterdam, 1993), pp. 167-77.

Porter, R., A Social History of Madness: Stories of the Insane (London, 1999).

Porter, R., and Micale, M. S., 'Introduction: reflections on psychiatry and its histories', in M. S. Micale and R. Porter (eds), Discovering the History of Psychiatry (New York and Oxford, 1994), pp.3-36.

Prior, L., The Social Organization of Mental Illness (London, 1993).

Prochaska, F. K., Women and Philanthropy in Nineteenth-Century England (Oxford, 1980).

Ramon, S., Psychiatry in Britain: Meaning and Policy (London, 1985).

Redfield Jamison, K., Touched With Fire: Manic Depressive Illness and the Artistic Temperament (New York, 1994).

Reid, F., 'Distinguishing between shell-shocked veterans and pauper lunatics: the ExServices' Welfare Society and mentally wounded veterans after the Great War', War in History, 14 (2007), 347-71.

Renvoize, E., 'The Association of Medical Officers of Asylums and Hospitals for the Insane, the Medico-Psychological Association, and their presidents', in G. E. Berrios and H. Freeman (eds), 150 Years of British Psychiatry, 1841-1991 (London, 1991), pp. 29-78. 
Rollin, H. R., 'The Red Handbook: an historic centenary', Psychiatric Bulletin, 10 (1986), 279.

Rolph, S., Atkinson, D. and Warmsley, J., “'A pair of stout shoes and an umbrella”: the role of the mental welfare officer in delivering community care in East Anglia: 1946-1970', British Journal of Social Work, 33 (2003), 339-59.

Rose, N., Governing the Soul: The Shaping of the Private Self (London, 1989).

Sartorius, N. and Schulze, H., Reducing the Stigma of Mental Illness: A Report from a Global Programme of the World Psychiatric Association (Cambridge, 2005).

Sayce, L., From Psychiatric Patient to Citizen: Overcoming Discrimination and Social Exclusion (Houndmills, 2000).

Scannell, P., 'Public service broadcasting: the history of a concept', in A. Goodwin and G. Whannel (eds), Understanding Television (London, 1990), pp. 11-29.

Scottish Government, Towards a Mentally Flourishing Scotland: Policy and Action Plan, 2009-2011 (Edinburgh, 2009).

Scull, A. T., Museums of Madness: The Social Organization of Insanity in NineteenthCentury England (London, 1979).

Scull, A., (ed.), The Asylum as Utopia: W. A. F. Browne and the Mid-Nineteenth Century Consolidation of Psychiatry (London and New York, 1991).

Scull, A., The Most Solitary of Afflictions: Madness and Society in Britain, 1700-1900 (New Haven and London, 1993).

Scull, A., 'Somatic treatments and the historiography of psychiatry', History of Psychiatry, 5 (1994), 1-12.

Scull, A., Madhouse: A Tragic Tale of Megalomania and Modern Medicine (New Haven and London, 2005).

Scull, A., MacKenzie, C. and Hervey, N., Masters of Bedlam: The Transformation of the Mad-Doctoring Trade (Princeton, 1996).

Searle, G. R., Eugenics and Politics in Britain 1900-1914 (London, 1976).

Shakespeare, T. and Watson, N., 'The social model of disability: an outdated ideology?', Research in Social Science and Disability, 2 (2002), 9-28.

Shorter, E., A History of Psychiatry: From the Era of the Asylum to the Age of Prozac (New York, 1997).

Shortland, M., 'Screen memories: towards a history of psychiatry and psychoanalysis in the movies', British Journal for the History of Science, 20 (1987), 421-52.

Showalter, E., The Female Malady: Women, Madness and English Culture, 1830-1980 (1987; London, 2001).

Small, H., "In the guise of science": literature and the rhetoric of nineteenth-century English psychiatry', History of the Human Sciences, 7 (1994), 27-55.

Smith, J., "Forging the "missing link": the significance of the Mental After Care Association archive', History of Psychiatry, 8 (1997), 407-20.

Soanes, S., 'Reforming asylums, reforming public attitudes: J. R. Lord and Montagu Lomax's representations of mental hospitals and the community, 1921-1931', Family and Community History, 12 (2009), 117-29. 
Soanes, S., 'Rest and Restitution: Mental Convalescence and the English Public Mental Hospital, 1919-1939' (PhD thesis, University of Warwick, 2011).

Spandler, H., Asylum to Action: Paddington Day Hospital, Therapeutic Communities and Beyond (London, 2006).

Spandler, H., 'From social exclusion to inclusion? A critique of the inclusion imperative in mental health', Medical Sociology Online, 2:2 (2007), 3-16.

Stedman Jones, G., Outcast London: A Study in the Relationship between Classes in Victorian Society (1971: Harmondsworth, 1992).

Stewart, J., 'Angels or aliens? Refugee nurses in Britain, 1938 to 1942', Medical History, 47 (2003), 149-72.

Stewart, J., 'Psychiatric social work in inter-war Britain: child guidance, American ideas, American philanthropy', Michael Quarterly, 3 (2006), 78-91.

Stewart, J., "II thought you would want to come and see his home”, child guidance and psychiatric social work in inter-war Britain', in M. Jackson (ed.), Health and the Modern Home (Abingdon, 2007), pp. 111-27.

Stewart, J., 'The scientific claims of British child guidance', British Journal for the History of Science, 42 (2009), 407-32.

Stewart, J., Child Guidance in Britain, 1918-1955: The Dangerous Age of Childhood (London, 2013).

Strong, S., Community Care in the Making: A History of MACA 1879-2000 (London, 2000).

Sturdy, S., 'Hippocrates and state medicine: George Newman outlines the funding policy of the Ministry of Health', in C. Lawrence (ed.), Greater than the Parts: Holism in Biomedicine, 1920-1950 (Oxford, 1998), pp.112-34.

Sturdy, S., (ed.), Medicine, Health and the Public Sphere in Britain, 1600-2000 (London, 2002).

Suzuki, A., Madness at Home: The Psychiatrist, the Patient, and the Family in England, 1820-1860 (Berkley and Los Angeles, 2006).

Tansey, E. M., "They used to call it psychiatry": aspects of the development and impact of psychopharmacology', in M. Gijswijt-Hofstra and R. Porter (eds), Cultures of Psychiatry and Mental Health Care in Postwar Britain and the Netherlands (Amsterdam, 1998), pp.79-101.

Taylor, B., 'The demise of the asylum in late twentieth-century Britain: a personal history', Transactions of the Royal Historical Society, 21 (2011), 193-215.

Thom, B., Dealing with Drink: Alcohol and Social Policy from Treatment to Management (London, 1999), pp.36-9.

Thom, D., 'Wishes, anxieties, play and gestures: child guidance in inter-war England', in R. Cooter (ed.), In the Name of the Child: Health and Welfare, 1880-1940 (London, 1992), pp. 200-19.

Thomson, M., The Problem of Mental Deficiency: Eugenics, Democracy, and Social Policy in Britain, c. 1870-1959 (Oxford, 1998).

Thomson, M., 'Status, manpower and mental fitness: mental deficiency in the First 
World War', in R. Cooter, M. Harrison and S. Sturdy (eds), War, Medicine and Society (Stroud, 1998), pp. 149-66.

Thomson, M., Psychological Subjects: Identity, Culture and Health in Twentieth-Century Britain (Oxford, 2006).

Todd, S., Young Women, Work, and Family in England 1918-1950 (Oxford, 2005).

Toms, J., 'Mental Hygiene to Civil Rights: MIND and the Problematic of Personhood, c.1900-c.1980' (PhD thesis, University of London, 2005).

Toon, E., "Cancer as the general population knows it": knowledge, fear, and lay education in 1950s Britain', Bulletin of the History of Medicine, 81 (2007), 116-48.

Topp, L., Moran, J. and Andrews, J. (eds), Madness, Architecture and the Built Environment: Psychiatric Spaces in Historical Context (Abingdon, 2007).

Trent Jr, J. W., Inventing the Feeble Mind: A History of Mental Retardation in the United States (Berkeley and Los Angeles, 1994).

Tringo, J. L., 'The hierarchy of preference towards disability groups', Journal of Special Education, 4 (1970), 295-30.

Turner, T., "Not worth powder and shot": the public profile of the MedicoPsychological Association, c. 1851-1914', in G. E. Berrios and H. Freeman (eds), 150 Years of British Psychiatry, 1841-1991 (London, 1991), pp.3-16.

Ungerson, C., Policy Is Political: Sex, Gender and Informal Care (London, 1987).

Ussher, J., Women's Madness: Misogyny or Mental Illness? (London, 1991).

Vincent, A. W., 'The Poor Law reports of 1909 and the social theory of the Charity Organisation Society', Victorian Studies, 27 (1984), 343-63.

Webster, C., 'Healthy or hungry thirties?', History Workshop Journal, 13 (1982), $110-29$.

Westwood, L., 'Avoiding the Asylum: Pioneering Work in Mental Health Care, 18901939' (DPhil thesis, Sussex University, 1999).

Westwood, L., 'A quiet revolution in Brighton: Dr Helen Boyle's pioneering approach to mental health care, 1899-1939', Social History of Medicine, 14 (2001), 439-57.

White, H., The Content of the Form: Narrative Discourse and Historical Representation (Baltimore and London, 1987).

Woodroofe, K., From Charity to Social Work in the United States and England (London, 1962).

Wright, D., 'The discharge of pauper lunatics from county asylums in mid-Victorian England: the case of Buckinghamshire', in J. Melling and B. Forsythe (eds), Insanity, Institutions and Society 1800-1914: A Social History of Madness in Comparative Perspective (Abingdon, 1999), pp.93-112.

Yanni, C., The Architecture of Madness: Insane Asylums in the United States (Minneapolis and London, 2007).

Younghusband, E., Social Work in Britain: 1950-197. A Follow-Up Study Vol. 2 (London, 1978). 


\section{Internet sources}

Andrews, J., 'Savage, Sir George Henry (1842-1921)', Oxford Dictionary of National Biography, Oxford University Press, 2004; online edition, May 2007: www. oxforddnb.com/view/article/38635.

Beresford, P., 'Mental health discrimination is coming from the top, not the public', The Guardian (30 November 2011): www.guardian.co.uk/society/joepublic/2011/ nov/30/mental-health-discrimination-campaign.

Corley, T. A. B., 'Wakefield, Charles Cheers, first Viscount Wakefield (1859-1941)', Oxford Dictionary of National Biography, Oxford University Press, 2004; online edition, January 2011: www.oxforddnb.com/view/article/36679.

Department of Health, ' $£ 20$ million to knock down mental health stigma', 10 October 2011: http://mediacentre.dh.gov.uk/2011/10/10/20-million-to-knockdown-mental-health-stigma/.

Digby, A., 'Tuke, Daniel Hack (1827-1895)', Oxford Dictionary of National Biography, Oxford University Press, 2004: www.oxforddnb.com/view/article/27804, accessed 15 November 2011.

Firemonkee, 'Time to Change': www.mentalhealthforum.net/forum/thread4637. html, 10 May 2011.

Fisher, P., 'James Bickford', Guardian, 3 April 2009: www.guardian.co.uk/ theguardian/2009/apr/03/obituary-james-bickford.

'Health: Dobson outlines Mental Health Plans', 29 July 1998: http://news.bbc. co.uk/1/hi/health/141651.stm.

Hornstein, G., 'Bibliography of first-person narratives of madness in English (5th edition)', last revised December 2011: www.gailhornstein.com/files/Bibliography_ of_First_Person_Narratives_of_Madness_5th_edition.pdf.

Lentin, A., 'McCardie, Sir Henry Alfred (1869-1933)', Oxford Dictionary of National Biography, Oxford University Press, 2004: www.oxforddnb.com/view/ article/34677, accessed 10 October 2011.

Lombard, P., 'Mental Health Act: demand for community orders swamps services', Community Care, 30 March 2009: www.communitycare.co.uk/articles/ 30/03/2009/111151/mental-health-act-demand-for-community-orders-swampsservices.htm.

http://mary-barnes.net/about.htm, consulted 17 February 2012.

Mental Health Foundation, 'What are mental health problems?': www.mentalhealth. org.uk/help-information/an-introduction-to-mental-health/what-are-mental-heal th-problems/?view =Standard, accessed 30 January 2012.

Mind: www.mind.org.uk/.

Powell, E., speech given to the National Association for Mental Health (1961): reproduced on the webpage http://studymore.org.uk/xpowell.htm.

Rethink Mental Illness: http://www.rethink.org/.

Roberts, A., 'Mental Health History Timeline': http://studymore.org.uk/.

Royal College of Psychiatrists: www.rcpsych.ac.uk.

Russell, K. F. 'Berry, Richard James Arthur (1867-1962)', Australian Dictionary of 
Biography (1979): http://adb.anu.edu.au/biography/berry-richard-james-arthur5220/text8703, accessed 8 February 2013.

See Me: www.seemescotland.org.

Springhall, J., 'Brabazon, Reginald, twelfth earl of Meath (1841-1929)', Oxford Dictionary, of National Biography, Oxford University Press, 2004; online edition, January 2011: www.oxforddnb.com/view/article/32019.

'This week in ..., Worcester News (August 18 2008): www.worcesternews.co.uk/ news/nostalgia/thisweekin/3601926.AUGUST_16_23/.

Time to Change: www.time-to-change.org.uk.

Together, 'Henry Hawkins: Founder of Together': www.together-uk.org/uploads/ pdf/history/henryhawkins.pdf, accessed 8 November 2011.

http://topdocumentaryfilms.com/how-mad-are-you/, consulted 17 February 2013.

Willis, S., 'Shiny happy service users - is the TTC campaign about to become counterproductive?', 18 September 2010: www.dawnwillis.wordpress.com/2010/09/18/ shiny-happy-service-users- $\% \mathrm{E} 2 \% 80 \% 93$-is-the-ttc-campaign-about-to-become-cou nter-productive/. 